\title{
Inclusion or Exclusion Ramifications of Teenage Pregnancy: A Comparative Analysis of Namibia and South African Schools Pregnancy Policies
}

\author{
Mashishi N \\ Email: normanm@uj.ac.za
}

Makoelle T

Email: tmakoelle@uj.ac.za

\section{Doi:10.5901/mjss.2014.v5n14p374}

\section{Abstract}

Pregnancy of learners for most South African schools has reached alarming proportions. To most governing bodies and teachers, it has becomes difficult to deal with pregnancy of learners. What makes this a conundrum is that teachers don't know what should be done for the well-being of the pregnant leaner, the baby and the fear that learners and teachers who may have to provide medical help should medical problems arise are not prepared. South African constitution forbids excluding pregnant learners from school and allows them (Pregnant learners) to continue with their schooling. The school governing bodies of most schools responded by formulating pregnancy policies which forbids a pregnant learner from continuing with her schooling when her pregnancy in the seventh to eight month and not to return to school immediately after the child is born. In some schools, a pregnant learner must be accompanied by an adult at all times for such a learner to continue with her schooling. Denying pregnant girls access to education is a denial of their fundamental human rights. This paper explores how schools through school governing bodies have modelled their pregnancy policy on the Department of Basic Education document entitled "Measures for the Prevention and Management of Learner Pregnancy". This paper also argues that the document referred above has some aspects which are unconstitutional like the exclusion from school by a pregnant learner for up to two years. Using a comparative analysis, the guidelines contained in the document referred above, are then compared with the ones from the neighbouring country of Namibia. The aim is to draw lessons from how Namibia deals with the prevalence of learner pregnancy in schools.

Keywords: inclusive education, inclusion policy, teenage pregnancy, teenager

\section{Introduction}

The South African department of education implemented inclusive education. Inclusive education spells out that all learners regardless of their background needs to be taught in the mainstream classrooms and any form of exclusion should be discouraged. The White paper 6 (2001) which is a policy framework with regard to inclusion, makes it clear that any form of exclusion from school constitutes a violation of learner's right to education. However the inclusion of pregnant learners in schools has remained a conundrum. Prior to a new democratic dispensation in 1994, pregnant learners were expelled from schools immediately when it became known that they were pregnant. Currently, there is no clear policy yet regarding when a pregnant learner should leave school in order to deliver the child. This has resulted in some schools asking their pregnant learners to leave school when their pregnant state become noticeable. The second problem with learner pregnancy is when to allow them back after birth resulting with some schools accepting their re-entry into school from three months to a year.

Articles 1(a) and 1(b) of our constitution states that the Republic of South Africa (1993) is founded on among others, the following values:

Human dignity, the achievement of equality and the advancement of human rights and freedoms.

Non-racialism and sexism. These principles are reinforced in chapter 2 of the constitution, the Bill of Rights, which is relevant to this article. We should take special note of Article 9(3) which declares that the state may not unfairly discrimination directly or indirectly against anyone on one or more grounds including race, gender, sex, pregnancy, marital status, ethnic or social origin, colour, sexual orientation, age, disability, religion, conscience, belief, culture, language and birth. Article 29(1) declares that everyone has the right to a basic education including adult basic education.

Gender equality, it has since become a centrepiece of legislation and policy in all spheres. The South African 
schools Act (1996) stipulates a variety of measures to implement gender transformation among them, it protects pregnant learners and safeguarding them from expulsion. Despite all these a question worth asking is:

How can teenage pregnant learner be included within the school context?

In order to address this question, it is important to put the problem into context.

\section{Teenage Pregnancy and Education}

The relationship between teenage pregnancy and education is most problematic one. In South Africa, it has become a media focus partly because of an unfolding longitudinal court cases that involve school policy on pregnant learners. According to Hubbard (2012) a girl leaner could become pregnant as a result of being coerced into having sex, against her will by means of physical force, economic background or peer pressure. The father may be a schoolboy, a teacher, a 'sugar daddy' or even a relative. However the question is what this will mean for her future because of this premature pregnancy. The causes of teenage pregnancy are listed by among others, Tsebe (2010), Rangiah (2012) as less openness and transparency about sexuality and financial difficulties experienced by teens as a result of abject poverty. Teenage pregnancy changes a teenager's life forever and this change is mostly negative. Runhare \& Vandeyar (2012) posit that teenage pregnancy is highly stigmatised in African communities. In education, the concern is about valuable learning time lost and the responsibilities that go with motherhood. This motherhood may mean that the teenager will have to give up her own education to take care of the baby. Teenagers who become pregnant are more likely to drop out of school and those teenagers who drop out of school are more likely to become pregnant again. Becoming a parent is a leading cause of dropping out of school among girls in many countries (Tsebe 2010). Malahlela (2012) goes on to postulate that the teenage pregnancy affect the emotional behaviour of teens and relationships with significant others. The problem of teenage pregnancy among schoolgirls is a major concern in many countries and so is the drive towards the elimination of gender disparities in education.

The importance of education particularly for the girl child has long been cited as a critical factor in the development of nations, and in the achievement of the Millennium Development Goals which place the achievement of universal primary education second only to eradication of extreme poverty and hunger. Hubbard (2012) argues that the social benefits of educating women in particular include improved agricultural productivity, improved health and reduction in infant and child mortality rates. Furthermore, on the African continent where the adage when you educate a woman you educate a nation holds so true, the repercussions of girls dropping out of school due to a school's policy on pregnancy are dire.

Due to the fact that teenage pregnancy among schoolgirls is a major concern in many countries and a constraint in the elimination of gender disparities in education, it therefore becomes imperative for countries to have a pregnancy policy that clearly spells out what the schools must do when dealing with pregnant leaners. This unfortunately is left in the hands of School Governing Bodies (SGBs) whose policies are somehow seen being in contravention to the constitution of the Republic of South Africa when it comes to retention of pregnant learners and their return to schools.

\section{South Africa's Current Policy on Teenage Pregnancy}

In a rights-based society, young girls who fall pregnant should not be denied access to education and this is entrenched in law through the constitution and the Schools Act no 84 of 1996. Based on this, the Department of Basic Education (DoBE) developed some guidelines pertaining to teenage pregnancy in schools. These guidelines seek to protect young pregnant school girls' right to education. A decision was taken by the Council of Education Ministers (CEM) in 2000 in which pregnant learners could no longer be expelled from any public school. However, this did not stop some schools from continuing to expel pregnant learners (Panday, Makiwane, Ranchod \& Letsoalo, 2009). This according to Runhare \& Vandeyar (2011) is caused by the fact that communities pursue a socio-cultural value system which is alien to the one held by policy. The guidelines that have been introduced, recognises the responsibility and influence of both the education system together with the larger community in prevention and management of teenage pregnancy. Be that as it may, the role of communities have been influenced by their moral beliefs rather than democratic values of the South African constitution. The emphasis in as far as the guidelines are concerned is more on the prevention and reduction of teenage pregnancy, HIV and other sexuality transmitted diseases (Panday, Makiwane, Ranchod \& Letsoalo, 2009). In the event of the occurrence of unplanned pregnancy, the education system must have processes and procedures to manage such pregnancies appropriately. According to the guidelines, an attempt is being made to balance the right of the pregnant school girl to education and equality against the rights of the new born child to care and support. Also, there is a waiting period suggested in these guidelines of two years which many think might compromise the educational attainment 
of pregnant girls. What it means is that South Africa's guidelines/policy allows pregnant girls to remain in school as determined by each school's Governing Body and to return to school after the birth of the child. The period the pregnant girl has to stay at home after the birth of the child is determined by the school governing body in its pregnant policy.

However, teenage pregnancy continue to affect the education of girls negatively for instance only a third of the teen mothers earn their high school diploma and consequently affecting their children as well because girls born to teen mothers are more likely to be teen mothers themselves.

To help in unravelling this problem of learner pregnancy in schools it is appropriate to draw some lessons from Namibia's policy of learner pregnancy as Namibia has experienced similar problem.

\section{Namibia's Leaner Pregnancy Policy}

Learner pregnancy like in South Africa is a concern to authorities of education in Namibia. Namibia like South Africa, prior 1994 left the decision on learner pregnancy to the discretion of individual schools. Expectation learner used to be expelled as soon as the authorities learned about their pregnancies. This also applied to the decision on whether to readmit them after they had delivered the baby. The first written policy on learner pregnancy was released and published in 1994 by the ministry of Education and was updated in 1995. According to the new policy, the pregnant learner who has been excluded from school because of pregnancy, 'may' be readmitted to their former schools or to another only if they are within the permissible age (Hubbard 2012: 227). Like in South Africa, the decision to readmit young mothers was left at the discretion of the individual school. The policy stipulates that the pregnant learner may continue with her education until the time of her confinement or an earlier date on the advice of a medical practitioner or clinic sister. After giving birth and on the advice of the social worker who shall have ensured that the infant will be cared for by a responsible adult, the girl shall have the right of admission to the same school within twelve months of the date on which she left school irrespective of her age. This policy was reviewed in 1997 and again in 1999 while in 2001 a study commissioned to review the implementation of the policy on teenage pregnancy recommended the policy which focused on support rather than punishment (Hubbard 2012: 228). The establishment of bridging centres where young mothers could continue with their education while breastfeeding and also the introduction of flexible models of attendance to provide additional opportunities for pregnant learners and young mothers to carry on with their classes (Hubbard 2012: 228). In 2009, the Namibian cabinet approved a new policy which allows a pregnant learner to remain in school until four weeks before the due date and to return to school shortly after giving birth if they wish provided that the baby is in good health. Alternately the young mother can stay for a longer period of time with the infant for a maximum period of one calendar year. This policy does help in ensuring that pregnant learners are not losing out on education as part of reality Vision 2030 which is geared towards a Learning Nation for Industrialisation and a better life to all and is based on the following six principles:

- The right to education

- Presentation by means of positive interventions rather than punishment

- Providing learners with appropriate information about reproductive health matters to encourage responsible decision-making

- Respect for the right to freedom of choice as well as respect for the dignity of the individual

- Support to learner-parents to help them complete their education in a manner which takes into account the health and welfare of the newborn child, and

- Respect for cultural and family values by providing sufficient flexibility to allow for a range of options (Hubbard 2012).

\section{The School Governing Bodies Role in Policy Formulation in South Africa}

In the new education dispensation the department of education has committed itself to transformation in all spheres including the governance of schools. New policies aimed at bringing about the goals of equity and redress, and to enhance democracy and participation of all groups in decision making processes at all levels have been adopted. Basic to transformation and change in school governance in post-apartheid South Africa was the implementation of South African Schools Act ,1996 (Act 84 of 1996) which has transferred formal powers of school governance to parents, teachers and learners (RSA 1996). According to Mathonsi in Singh, Mbokodi and Msila (2004) the motive behind the doctrine and philosophy of South African schools Act (SASA) is to encourage schools to become self-managing and selfgoverning where principals manage the day-to-day running of schools with members of SMT, and also members of democratically elected SGBs being responsible for school governance. In this case the Act makes it possible for all 
schools to establish SGBs with powers and functions making each school self-governable and unique with its policies but operating within the parameters of the constitution. According to the Act, a school can buy, sell, hire or own property, enter into contracts, make investments, and sue or be sued through the School Governing Body as legal entity with decisions-making powers concerning the school (Potgieter, Visser, Vand der Bank, Mothatha and Squelch, 1997:12).

To many, participation in schools decision-making process has long been seen as critical to democratic schools governance. The processes and structures maximise parents and learner involvement and participation. To create school environments where participation takes place, the new political dispensation introduced decentralisation of decision making powers to school governing bodies composed of parents, teachers and learners. The school governing body is constituted by the school principal, democratically elected parents, teachers, non-teaching staff, learners (in secondary schools) as well as co-opted non-voting members. The responsibility of overseeing the operation of the state education was assigned to the newly established nine provisional Departments of Education while the responsibility of managing the schools was vested in each school's elected school governing body (SGB) which by design is dominated by parents (RSA ,1996:16).

The South African schools Act has given the school governing body to make policies around issues pertinent to schools like language, religious instruction, school fees, admission, a code of conduct and learner pregnancy policy. The policies made by the school governing body must be guided by the South African School Act and the country's constitution which means that policies developed at schools which among others:

- allow all South African to enter the school system

- promote values of non-racialism and equality between boy and girl learners

- help communities to respect and tolerate all regions and cultures in our country

- encourage children to speak a range of our country's language

- respect children`s right and promote non-violent ways of solving problems

This gives effect to section 195 of the South African constitution (Act 108 of 1996) particularly the principle of public participation in policy making for public institution as enshrined in subsection 1(e) (RSA 1996). In formulating policies as mentioned earlier, the school governing body should ensure that there is nothing in their policy that is inconsistent with South African schools Act and the constitution. This has proved to be problematic as evidenced by the number of cases that has been instituted against school governing bodies such as the one involving the Gauteng Department of Education against the governing body of Rivonia Primary over admission policy, the Free State school whose learner pregnancy policy provided for the automatic expulsion of pupils for up to a year (Mkize 2013:4) . In a similar incident, the school governing body of Lenasia high school has changed its pregnancy policy following the intervention of the Equal Education Law Centre after a girl learner was prevented from coming to school during her school's June examination. This intervention had come after the pupil had missed a month of school including a mid-year exam (Star reporter 2013: 2).

The difficulties and obstacles the school governing bodies of different schools are faced with particularly with the formulation of learner pregnancy policy is balancing the right to education of a learner as per the constitution and the teachers' concern of what is to be done if a learner goes on labour during school hours. This leaves policy stakeholders wanting as evidenced by the cases mentioned earlier indicate. Policies on learner pregnancy are divided into expulsion, re-entry and continuation policies. It is appropriate to argue that expulsion policies symbolised direct violation of girls" human rights. Continuation and re-entry policies are prevalent in countries that have ratified the Convention on the Elimination of all Forms of Discrimination against Women and the Convention on the Rights of Children. It is also argued that re-entry policies also violate girl's mothers' right to education through a retreat ideology that requires temporary withdrawal of the pregnant girl from school. This has created a big problem for the school governing bodies in developing a learner pregnancy policy which will be within the constitution. Learner pregnancy is one issue that cause policy stakeholders at school to often take different sides on an issue such as how to address the problem without compromising the pregnant leaners' chances of a better future by taking them out of the education system and on the other hand being wary that teachers at school are not trained midwives who can fully attend to a learner who might be faced with an immediate need to give birth. This presents a challenge to schools because of a lack of policy that stipulates what needs to be done should such a situation happen in the presence of educators at school.

\section{Lessons from Pregnancy Policy Analysis of Both South Africa and Namibia}

The analysis of policy development of two countries point on the following:

- that pregnancy should be viewed as a preventable phenomenon;

- that leaners who fall pregnant should not be subjected to any punitive punishment, but rather be guided of 
parenting while schooling;

- that policy should address the incongruences between the socio-cultural values and constitutional values;

- that policy implementation be followed by clear action plan to defuse role ambiguities by school stakeholders.

\section{Conclusion and Recommendations}

Although the government has introduced policies that are aimed at gender parity in basic education and that girl learners now make up the majority of enrolments in secondary schools, however pregnancy is amongst the major concerns that pose a serious threat to gains achieved thus far in public schools. Learner pregnancy undermines the Department's efforts to ensure that girl children remain in school in order to contribute towards a quality life for all, free of poverty. Strategies and processes that have been put in place lately are bearing fruit as the rate of teenage pregnancy is declining. Despite decline in teenage pregnancy, the Gauteng Department of Education has introduced various intervention programmes to increase access to quality education and improve learner behaviour through life-skills programmes as well as HIV and AIDS programmes in schools like the healthy living curriculum programmes that have been incorporated in the school curriculum to raise learner awareness and deal with change behaviour amongst learners. Among things that has to be done is to ensure that girl learners do not fall victim to early pregnancies through programmes like the ones introduced by the Gauteng Department of Education. These programmes do bear results because according to the DBE commissioned report ' Teenage pregnancy in South Africa with a specific focus on school going learners, learner pregnancy rates per province between 2004 and 2008, schools that Gauteng has the lowest number of pregnancy per 1000 registered learners.

Also Life Skills programmes have been added to the curriculum in schools wherein issues around learner pregnancy and HIV and AIDS is covered in the Personal and Social Well-being component of the subject. All in all, much has been done by the Department of Basic Education to combat learner pregnancy and the response has been good as more and more girl learners complete their matriculation resulting decline in fertility rate. The declining teen pregnancy rates have occurred in parallel with the institution of an enabling policy environment for young people like the increased availability of family planning services including termination of pregnancy, policies on life-skills education in schools and government funded campaigns. To help schools in managing learner pregnancies with a strong focus on longer retention and earlier return of pregnant girls. This policy should be adhered to by all public schools so that we bring to an end the current situation where we see the Provincial Head in the Department of education together with the courts are loggerheads with school governing councils because of learner pregnancy policies which are not in line with the South African Schools Act and Constitution.

The learner pregnancy policy should be formulated by the Department of Basic Education and should indicate clearly what and when schools need to do and when young mothers should return to school. This policy will then supplement the existing programmes for the prevention of HIV and other sexually transmitted infections which are done through Life Orientation learning area.

\section{References}

Department of Education. 2001. Education White Paper 6: Building an inclusive education and training and system. Pretoria: Government Printers.

Hubbard, D. in Ruppel O.C. 2009. Realizing the right to education for all: school policy on learner pregnancy in Namibia. Windhoek: Konrad Adenauer stiftung.

Malahlela, M.K. 2012. The effect of teenage pregnancy on the behaviour of learners at secondary schools in the Mankweng area, Limpopo. M Ed dissertation. Pretoria: UNISA

Mkhize, V. 2013. Teenage Pregnancy in schools: Johannesburg: The Star News Paper. March 25th: pp 7.

Ministry of Education 2008. School policy on learner pregnancy in Namibia: Background to reform: Gender Research \& Advocacy Project, Legal Assistance centre.

Mncube, V. 2009. The perceptions of parents of their role in the democratic governance of schools in South Africa: are they on board? South African Journal of Education, 29: 83-103.

Panday, S., Makiwane, M., Ranchod, C., \& Letsoalo, T. 2009. Teenage pregnancy in South Africawith a specific focus on school-going learners. Child, Youth, Family and Social Development, Human Sciences Research Council. Pretoria: Department of Basic Education.

Potgieter, J.M., Visser, P.J., Van der Bank, A.J., Mothata, M.S. \& Squelch, J,M. 1997. Understanding the South African schools Act. Pretoria: Government Printers.

Rangiah, J. 2012. The experiences of pregnant teenagers about their pregnancy. MNC dissertation. Stellenbosch: University of Stellenbosch 
Republic of South Africa. 1996. The Constitution of the Republic of South Africa Act No. 108 of 1993. Pretoria: Government Printers.

Republic of South Africa. 1996. The South African Schools Act No. 84 of 1996. Pretoria: Government Printers.

Runhare, T \& Vandeyar, S. 2012. Perceptions of policy duty bearers on the inclusive education policy for pregnant teenagers in South Africa. Journal of Social Sciences, 31 (1): 51-62.

Runhare, T \& Vandeyar, S. 2011. Loss of learning space within a legally inclusive education system: institutional responsiveness to mainstreaming of pregnant learners in formal education. Gender \& Behaviour, vol 9 (2): 4100-4124.

Singh, P., Mbokodi, S.M. \& Msila, V.T. 2004. Black parental involvement in Education. South African Journal of Education, 24 (4): $301-$ 307.

Tsebe, N.L. 2010. Factors contributing to teenage pregnancy as reported by learners at Mpolokong high school in the North-West province. MPH dissertation. Medunsa: University of Limpopo. 